\title{
Acaricidal Activity and Chemical Characterization of Helichrysum bracteatum and Salvia officinalis Leaf Extracts Against Tetranychus urticae and Its Predator, Stethorus gilvifrons (Coccinellidae)
}

\author{
Manal S. Ismail*; Nesrin A. EI Basha ${ }^{* *}$ and Said A. Allam* \\ "Vegetable and Ornamental Plant Mites Dept., Plant Prot. Res. Inst., Agric. Res. Center, Egypt. \\ ${ }^{* * *}$ Biological Control Dept., Plant Prot. Res. Inst., Agric. Res. Center, Egypt.
}

\begin{abstract}
This study presents an attempt to evaluate the acaricidal activity of the two medicinal plants, Helichrysum bracteatum L. (Asteraceae) and Salvia officinalis L. (Lamiaceae) against Tetranychus urticae Koch and its predator, Stethorus gilvifrons Muls. under laboratory conditions. The ethanolic leaf extracts of $\mathrm{H}$. bracteatum [HbLE $\mathrm{EtOH}_{0 \%}$ ] and $S$.officinalis [SoLE $E_{\mathrm{EtOH} 70 \%}$ ] were assessed for their direct toxicity against T. urticae and S. gilvifrons adult females. Both extracts were assessed for their effects on the egg-laying capacity, repellent and oviposition deterrent effects of the T. urticae adult females, as well as their direct effects on T. urticae eggs. The chemical characterization of both extracts was conducted to investigate their bioactive components by gas chromatography (GC-MS). Based on acute toxicity, results showed that $\mathrm{HbLE}_{\mathrm{EtOH} 70 \%}$ displayed the highest acaricidal activity $\left(\mathrm{LC}_{50}=1.27 \%\right)$ followed by SoLE $\mathrm{EtOH}_{70 \%}(3.39 \%)$ against $T$. urticae adult females. Whereas, against $S$. gilvifrons adult females, SoLE $\mathrm{EtOH}_{70 \%}$ was less toxic $\left(\mathrm{LC}_{50}=37.06 \%\right)$ than $\mathrm{HbLE}_{\mathrm{EtOH} 70 \%}$ $\left(\mathrm{LC}_{50}=0.76 \%\right)$. Our results revealed that $\mathrm{HbLE}_{\mathrm{EtOH} 70 \%}$ and $\mathrm{SoLE} \mathrm{EtOH}_{70 \%}$ had a significant effect on the egg-laying capacity of T. urticae adult females. According to the repellent index (RI), the HbLEEtoH70\% and SoLE $\mathrm{EtOH}_{70 \%}$ were classified as repellent. Both extracts revealed a potent ovicidal effect, where the egg hatching percentage was $48.75 \pm 15.38$ and

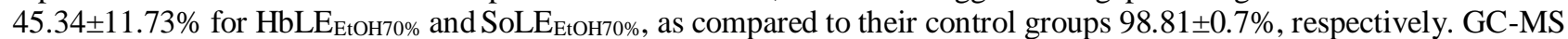
analysis showed that phytol was the major component of $\mathrm{HbLE}_{\mathrm{EtOH} 70 \%}$ and SoLE $\mathrm{EtOH}_{70 \%}$. The current study confirmed the potent acaricidal effect of $H$. bracteatum and $S$. officinalis leaf extract against $T$. urticae. Thus, the $S$. officinalis leaf extract was the safe acaricidal product suitable for use in integrated pest management strategies as it was safe for S. gilvifrons.
\end{abstract}

Key words: Tetranychus urticae; Stethorus gilvifrons; Helichrysum bracteatum; Salvia officinalis; leaf extract; acute toxicity.

\section{INTRODUCTION}

The two-spotted spider mite, Tetranychus urticae Koch is the chief agricultural pest of approximately 1,100 plant species invading more than 140 different families (Grbic et al., 2011). Given that $T$. urticae breeds healthily through adapting to various plant species, it could be explained as it deactivated various secondary metabolites such as toxins, repellants and nutritional inhibitors, which are the key units of defense mechanisms (Smith and Clement, 2012). Hence, to get over this mite resistance, we conducted many research works to establish an alternative method in use of novel acaricides from natural plant products whether in form of extract or essential oil taking in consideration to be exceedingly specific to $T$. urticae compatible to its predator at the prescribed dosage (El Ouali et al., 2016).

The spider mites biological control has focused on two bunches of biocontrol agents, the predatory mites within the family Phytoseiidae and the different Stethorini species (Coleoptera, Coccinellidae) (Roy et al., 2005). The ladybird beetle, Stethorus gilvifrons (Muls.) is the gluttonous predator in the Middle East that can effectually control spider mite populations as it feeds on both juvenile and adult spider mites (Biddinger et al., 2009).
Since the plant extract compounds are found in nature so they do not release toxic substances into the environment and did not cause water pollution by decomposing quickly (Salman et al., 2014). Therefore, several plant extracts has been investigated, as potential sources of commercial mite control agents because of their nature multi components that are less susceptible to the development of resistance (Kumral et al., 2010).

Accordingly, Helichrysum bracteatum (Asteraceae), the golden everlasting as commonly known, contains a distinctive reservoir of various secondary metabolites that imparts them great medicinal properties. In the Mediterranean region, Helichrysum is widely used in traditional medicine as skin repair, likewise, the genus is described to possess anti-inflammatory, antimicrobial and antioxidant properties (Sala et al., 2002).

Similarly, Salvia officinalis L. (Lamiaceae), called meramiya in the neighborhood, is native also to the Mediterranean region. It is a potent medicinal herb used in folk medicine, as it is very rich in biologically active compounds increasing its medicinal importance (Beheshti-Rouy et al., 2015).

Different Helichrysum and Salvia species extracts were used as potential insecticides (Pascual- 
Villalobos and Robledo, 1999; Pavela, 2004). Few studies dealt with their acaricidal activities (Erdogan et al., 2012; Salman et al., 2014; Waked, 2016). However, no studies have demonstrated the impact of these plant extracts on natural enemies, thus increasing the need to study their effects on beneficial organisms.

Therefore, this study aims to screen the bioactivity of the leaf extracts of two medicinal plant species against the adult stage of $T$. urticae and S. gilvifrons for the first time. Furthermore, we investigate their phytochemical active components through a GC-MS analysis.

\section{MATERIALS AND METHODS}

\section{Plants collection and extract preparations:}

$H$. bracteatum and $S$. officinalis, the nominated plants for the study were collected in April 2017 from El Orman Garden, Cairo. Identification and extraction of the collected plants were executed at the Botany and Chemistry Dept., Faculty of Science, Suez Canal University, Ismailia, Egypt, respectively.

According to Breuer and Devkota (1990), the fresh leaf samples from the collected plants with known weight were air dried in the shade, grounded into a fine powder, and then immersed in a sufficient quantity of ethanol (EtOH) for $24 \mathrm{~h}$ with continuous shaking. Extracted solute was separated from the insoluble plant materials, collected and the later reextracted again with $\mathrm{EtOH}$ for another $24 \mathrm{~h}$ to ensure good extraction of ethanol soluble constituents, then the solvent was separated. The extract was then filtrated and ethanol was evaporated at reduced pressure at $40^{\circ} \mathrm{C}$, to dryness in a rotation evaporator to obtain the crude extract. After complete evaporation of the solvent, the extract was lyophilized, and stored in a refrigerator at $4{ }^{\circ} \mathrm{C}$ to avoid contamination.

\section{T. urticae and $S$. gilvifrons stock cultures:}

The susceptible strain of $T$. urticae and $S$. gilvifrons used in this study was originated from infested leaves of castor bean plants at Ismailia Agriculture Research Station, Ismailia, Egypt. The susceptible mite population was reared on sweet potato leaves in a climate-controlled room $27 \pm 2^{\circ} \mathrm{C}$, under $60 \pm 5 \%$ R. H. and $16 / 8 \mathrm{~h}$ of Light/Dark photoperiod). Adults of $S$. gilvifrons were reared on potato leaves heavily infested with $T$. urticae as described by Rott and Ponsonby (2000).

\section{Bioassays:}

\subsection{Adulticidal Bioassays:}

3.1.1. Acute toxicity for $T$. urticae and its predators S. gilvifrons adult females:

The acaricidal activity bioassay was carried as described by Erdogan et al. (2012). Leaf spray method using a Sigma glass spray (unit No. S 3135) and leaf disc method were used (Helle and Overmeer, 1985). Before the proper test, the toxicity of the ethanolic leaf extracts of $H$. bracteatum [HbLE $\mathrm{EtOH} 70 \%]$ and S. officinalis [SoLE $\left.\mathrm{EtOH}_{\mathrm{E} 0 \%}\right]$ was assessed by some preliminary tests to establish the appropriate concentration ranges needed. Bioassays were carried out by spraying five serially diluted concentrations $(0.375,0.75,1.5,3$, and $6 \%)$ for $\mathrm{HbLE}_{\mathrm{EtOH}} 7 \%$ and $(0.5,1,2,4$, and $8 \%)$ for SoLE $E_{\mathrm{EtOH} 70 \%}$ in triplicates. Thirty adult female mites were gently transferred onto the sweet potato leafdisc $(3 \mathrm{~cm}$ diameter) in Petri dishes $(9 \mathrm{~cm}$ diameter). According to Kumral et al. (2010), two $\mathrm{ml}$ of the two ethanolic leaf extracts were applied topically and allowed to dry for $30 \mathrm{~min}$ at $27 \pm 2^{\circ} \mathrm{C}$. After drying, the Petri dishes were kept at $27 \pm 2^{\circ} \mathrm{C}$, under $60 \pm 5 \% \mathrm{R}$. H. and $16 / 8 \mathrm{~h}(\mathrm{~L} / \mathrm{D})$, in a climatically controlled chamber. In all the experiments, an $\mathrm{EtOH}(70 \%)$ solution was used as a control treatment. The experiment was repeated five times. Mortality of the adult females was observed and the number of living and dead mites was recorded after $24 \mathrm{~h}$.

The Petri-leaf disc method technique was adopted for the bioassay of the S. gilvifrons adult females with some amendments according to James (2003) with the same procedure and concentrations of $T$. urticae bioassay. However, bigger Petri-dishes $(12 \mathrm{~cm})$ and detached raspberry leaf discs $(6 \mathrm{~cm}$ diameter) were used and put on its lower surface, then twenty adult females of $S$. gilvifrons were confined (20 females/replicate). For each treatment, two $\mathrm{ml}$ of the leaf extract were applied topically. Four replicates were used. All the treated leaf discs were allowed to dry completely at room temperature and kept in a climate chamber at $27 \pm 2^{\circ} \mathrm{C}$ and $60 \pm 5 \% \mathrm{R}$. H. Thirty adult females of $T$. urticae were provided as prey to $S$. gilvifrons on each Petri-dish for each treatment. Adult female mortality was assessed $24 \mathrm{~h}$ posttreatment.

\subsubsection{Egg-laying capacity of $T$. urticae adult females:}

The egg-laying capacity was evaluated for $T$. urticae adult females according to Erdogan et al. (2012) using one sublethal concentration $(0.5 \%)$ of

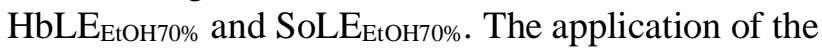
extract and the spider mites transferring to Petri dishes were the same as in the toxicity bioassays. Six replicates were used (15 \%/leaf disc) and each treatment was repeated ten times. The EtOH (70\%) was used as a control. The Petri dishes were putted in a climate chamber at $27 \pm 2{ }^{\circ} \mathrm{C}$, under $60 \pm 5 \% \mathrm{R}$. H. and $16 / 8 \mathrm{~h}$ (L/D). Daily monitoring and the eggs deposited on the discs during $72 \mathrm{~h}$ were counted. Fecundity of the treated females, i.e. the number of eggs laid per female at a $24 \mathrm{~h}$ interval, summed over $72 \mathrm{~h}$ was calculated. 


\subsubsection{Repellent and oviposition-deterrent effects on $T$. urticae adult females:}

The repellency test was performed using the leaf disc method where the $\mathrm{HbLE}_{\mathrm{EtOH} 70 \%}$ and SoLE $\mathrm{EtOH}_{\mathrm{E} 0 \%}$ were applied with one sublethal concentration $(0.5 \%)$. Repellent and oviposition-deterrent effects were assessed in a two-choice bioassay carried out in six replicates. Sweet potato leaf disks of $4.5 \mathrm{~cm}$ in diameter were used. Half of the disc was immersed for five seconds in the extract solution and after drying at room temperature, the other half was immersed in $\mathrm{EtOH}(70 \%)$ serving as a control. Each half circle was immersed in a way that permitted a free area of $0.3 \mathrm{~cm}$ between the two halves where the mites were initially released. Each disc was infested with ten adult females of $T$. urticae and each treatment was replicated six times. All Petri dishes were kept in a climate chamber at $27 \pm 2^{\circ} \mathrm{C}$, under $60 \pm 5 \%$ R. H. and 16/8 h (L:D). At 24, 48, and $72 \mathrm{~h}$, the number of mites and the eggs they laid present on treated and untreated leaf disc was counted. Repellency index (RI) and oviposition deterrence index (ODI) was calculated according to Kogan and Goeden (1970) and Dimetry et al. (1993), respectively.

\subsection{Ovicidal Bioassay:}

To assess the ovicidal activity of the HbLE $\mathrm{EtOH}_{\mathrm{E}} \%$ and the SoLE $E_{\mathrm{EtOH} 70 \%}$, a wide range of concentrations was tested to define the effective concentrations needed. Each disc of sweet potato leaves $(3 \mathrm{~cm}$ diameter) carried 100 eggs ( $24 \mathrm{~h}$ old) was sprayed by two ml of crude extract (8\%). A control group with $\mathrm{EtOH}(70 \%)$ was considered. Three replicates were used. All treated leaf discs were allowed to dry completely at room temperature and kept at $27 \pm 2^{\circ} \mathrm{C}$ and $60 \pm 5 \%$ R. H. in the laboratory. All discs were examined daily to record the number of hatched larvae (Chiasson et al., 2004). The eggs viability was checked for a period of seven days after oviposition. The eggs that did not hatch during this period were counted as non-viable.

\section{Gas Chromatography-Mass Spectrometry (GC-MS) analysis of the leaf extracts:}

The identification of the $H$. bracteatum and $S$. officinalis ethanolic leaf extract compounds was performed on a Thermo Scientific, Trace GC Ultra/ISQ Single Quadrupole MS instrument using a TG-5MS fused silica capillary column (30m, $0.251 \mathrm{~mm}, \quad 0.1 \mathrm{~mm}$ film thickness). Operating conditions were as follows: Helium as the carrier gas with a flow rate of $1 \mathrm{~mL} / \mathrm{min}$; column temperature $50^{\circ} \mathrm{C}$ for $2 \mathrm{~min}$ then increasing to $150^{\circ} \mathrm{C}$ for $2 \mathrm{~min}$ at an increasing rate of $7^{\circ} \mathrm{C} / \mathrm{min}$, then to $270^{\circ} \mathrm{C}$ for $2 \mathrm{~min}$ at an increasing rate of $5^{\circ} \mathrm{C} / \mathrm{min}$, then to 310 for 10 $\mathrm{min}$ as a final temperature at an increasing rate of $3.5^{\circ} \mathrm{C} / \mathrm{min}$; injector temperature, $280^{\circ} \mathrm{C}$; volume injected, $1 \mu \mathrm{L}$ (Thangavel et al., 2014). The GC/MS was recorded in electron ionization mode with energy of $70 \mathrm{eV}$. The total running time was completed within $58 \mathrm{~min}$. The relative percentage of each extract constituents was expressed as a percentage with peak area normalization. The identification of the bioactive phytochemical components was achieved through retention time and mass spectrometry by comparing the mass spectra of unknown peaks with those stored in WILEY and NIST libraries in the data system.

\section{Statistical Analysis:}

Mite and predator mean mortality rates $( \pm$ S.E. $)$ were calculated as a percentage of dead females. Concentration and mortality data were subjected to Probit analysis and $\mathrm{LC}_{50}$ value with a $95 \%$ confidence limit was estimated using the POLO Plus software (LeOra Software, Berkeley, CA, USA). Mortality, fecundity and repellency data were analyzed by oneway analysis of variance and the mean values were compared by Tukey's test $(\mathrm{p} \leq 0.05)$. For studying differences between groups, data were analyzed by one-way analysis of variance (ANOVA) after data normalization. All the statistical tests were performed using the software package SPSS 15.0.0.

\section{RESULTS AND DISCUSSION}

Acute toxicity of the $\mathrm{HbLE}_{\mathrm{EtOH70 \%}}$ and SoLE $_{\text {EtOH70\% }}$ against $T$. urticae and its predators $S$. gilvifrons adult females:

In the current investigation, we assessed the acute toxicity of $\mathrm{Hb}_{\mathrm{EtOH} 70 \%}$ and $\mathrm{So}_{\mathrm{EtOH} 70 \%}$ ethanolic leaf extracts against $T$. urticae and $S$. gilvifrons adult females (Figure 1). The five serially diluted concentrations used were $0.375,0.75,1.5,3$ and $6 \%$ for $\mathrm{HbLE}_{\mathrm{EtOH} 70 \%}$ and $0.5,1,2,4$ and $8 \%$ for SoLE $E_{\text {EtOH70\%, respectively. The HbLE }}$ EtOH70\% showed strong acaricidal activity against $T$. urticae and $S$. gilvifrons adult females. After $24 \mathrm{~h}$, the HbLE $\mathrm{EtOH}_{70 \%}$ at $6 \%$ showed the highest mean mortality rate $( \pm \mathrm{SE})$ $96.7 \pm 3.3$ and $100 \%$ against $T$. urticae and S. gilvifrons adult females, respectively, as compared to no mortality in their corresponding control groups $(\mathrm{P}<0.000)$. Whereas, the lowest mean mortality rate $( \pm \mathrm{SE})$ was $17.8 \pm 2.2$ and $30 \pm 2.9 \%$ at $0.375 \%$, respectively, as compared to no mortality in their corresponding control groups $(\mathrm{P}<0.000)$. Results showed that the $\mathrm{LC}_{50}$ value of $\mathrm{HbLE}_{\mathrm{EtOH} 70 \%}$ predicted by Probit analysis for adult females at $24 \mathrm{~h}$ was 1.27 and $0.76 \%$ for $T$. urticae and S. gilvifrons adult females, respectively. On the other hand, the $\mathrm{LC}_{50}$ of SoLE $E_{\mathrm{EtOH} 70 \%}$ was 3.39 and $37.06 \%$ for T. urticae and S. gilvifrons adult females, respectively.

Our results showed that $H$. bracteatum ethanolic leaf extract was more effective than that of the crude extract of $H$. arenarium tested by Erdogan et al. 
(2012) who recorded its highest mean mortality rate $82.38 \pm 1.92 \%$ at $12 \%$ while the lowest mortality rate was $39.76 \pm 5.18$ at $1 \%$. On the other hand, the highest mean mortality rate $( \pm \mathrm{SE})$ of $\mathrm{SoLE}_{\mathrm{EtOH} 70 \%}$ at $8 \% 24 \mathrm{~h}$ post-treatment was $85.3 \pm 3.5$ and $20 \pm 5 \%$ against $T$. urticae and $S$. gilvifrons adult females, respectively as compared to no mortality in their corresponding control groups $(\mathrm{P}<0.000)$. Whereas, the lowest mean mortality rate $( \pm \mathrm{SE})$ was $5.3 \pm 1.3 \%$ for $T$. urticae with no mortality in S. gilvifrons at $0.5 \%$ as compared to their corresponding control groups $(\mathrm{P}<0.000)$.

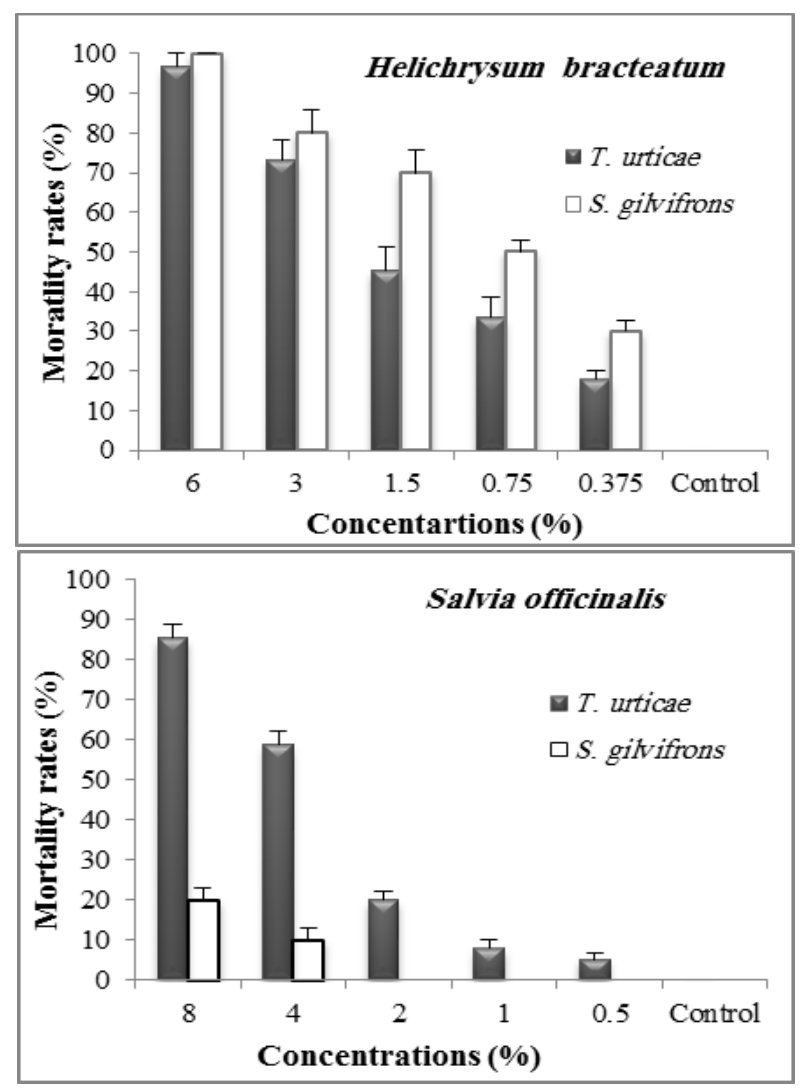

Fig. (1): Mean mortality rates ( \pm SE) of T. urticae and $S$. gilvifrons adult females treated with $\mathrm{HbLE}_{\mathrm{EtOH} 70 \%}$ and SoLEEtOH70\% $24 \mathrm{~h}$ posttreatments.

According to our result, it was found that the ethanolic leaf extract of S. officinalis $(8 \%)$ get a higher toxicity and mortality rates $24 \mathrm{~h}$ post-treatment than the methanolic leaf extract (12\%) exhibiting $62.2 \pm 0.03 \%$ mortality rates after 6 days as recorded by Salman et al. (2014). Similarly, Waked (2016) recorded the mortality rates of T. urticae adult females 44.28 and $31.42 \%$ for the methanol and aqueous leaf extracts of $S$. officinalis, respectively at the highest concentration used (20\%) after $24 \mathrm{~h}$.

No previous studies have investigated the impact of $\mathrm{HbLE}_{\mathrm{EtOH} 70 \%}$ and $\mathrm{SoLE}_{\mathrm{EtOH} 70 \%}$ on S. gilvifrons. However, the findings of other plant extracts belonging to the same plant families are similar to those of our study where Sarmah et al. (2009) found no mortality for the aqueous plant extract of
Xanthium strumarium (Asteraceae) and Clerodendron infortunatum (Lamiaceae). In addition to the different plant families as Acorus calamus (Acoraceae) and Polygonum hydropiper (Polygonaceae) even at higher concentration (10\%) for 14 days did not show any mortality against $S$. gilvifrons.

Another plant extracts belonging to different families were reported having acaricidal activity with similar mortality rates against $S$. gilvifrons including the ethanol leaf extract of Datura stramonium (Solanaceae) as recorded by Kumral et al. (2013) exhibited an $\mathrm{LC}_{50}$ of $0.18 \%$ after $24 \mathrm{~h}$. Similarly, Mazhawidza et al. (2018) found that the aqueous plant extract of Solanum delagoense (Solanaceae) was less toxic with an $\mathrm{LC}_{50}$ of $49 \%$, followed by $D$. stramonium $34 \%$ to Hippodamia variegata (Coleoptera: Coccinellidae). These results showed that $D$. stramonium and $S$. delagoense extracts were relatively safer to $H$. variegate. The present results indicated the ethanolic leaf extracts of $H$. bracteatum exhibited more significant effect than $S$. officinalis in the treatment of $T$. urticae but the latter was safer against its predator and can be included in integrated pest management programs.

\section{Assessment of the egg-laying capacity of $T$. urticae adult females:}

The effect of a sublethal concentration $0.5 \%$ of $\mathrm{HbLE}_{\mathrm{EtOH} 70 \%}$ and $\mathrm{SoLE}_{\mathrm{EtOH} 70 \%}$ on the egg-laying capacity of T. urticae adult females after 24, 48 and $72 \mathrm{~h}$ is shown in Table (1). Our results revealed that $\mathrm{HbLE}_{\mathrm{EtOH} 70 \%}$ and SoLE $\mathrm{EtOH} 70 \%_{\text {had }}$ a significant effect on the egg-laying capacity of the treated adult females.

They decreased the egg numbers to $10.43 \pm 0.3$ and $16.70 \pm 0.47$ eggs per female, respectively as compared to their control group (24.82 \pm 0.73 ) $(\mathrm{P}<0.000)$ summed after $72 \mathrm{~h}$ post-treatment. In contrast to our findings, Erdogan et al. (2012) found that $H$. arenarium crude extract even at (12\%) did not affect T. urticae fecundity. Regarding SoLE $\mathrm{EtOH}_{70 \%}$, our results was in agreements with Mohamed et al. (2015) who found that the ethyel acetate of $S$. officinalis extract reduced the total number of T. urticae eggs. Similarly, Tomczyk and Suszko (2011) found that the ethanolic leaf extract of $S$. officinalis diminished $T$. urticae female's fecundity.

\section{Assessment of the repellent and oviposition-} deterrent effects on $\boldsymbol{T}$. urticae adult females:

The repellent index (RI) and the oviposition deterrence index (ODI) of $\mathrm{HbLE}_{\mathrm{EtOH} 70 \%}$ and $\mathrm{SoLE}_{\mathrm{EtOH} 70 \%}$ at $0.5 \%$ on $T$. urticae adult females 24, 48 and $72 \mathrm{~h}$ post-treatment is shown in Tables $(2 \& 3)$. The behaviour of $T$. urticae adult 
Table (1): The egg laying capacity of $T$. urticae adult females treated with a sublethal concentration of the $\mathrm{HbLE}_{\mathrm{EtOH} 70 \%}$ and SoLEEtOH70\% (0.5\%) after 24, 48, and $72 \mathrm{~h}$.

\begin{tabular}{|c|c|c|c|c|c|c|}
\hline \multirow[b]{2}{*}{ Treatments } & \multicolumn{2}{|c|}{$24 \mathrm{hr}$. } & \multicolumn{2}{|c|}{$48 \mathrm{hr}}$. & \multicolumn{2}{|c|}{$72 \mathrm{hr}}$. \\
\hline & Mean Egg No. & $\begin{array}{c}\text { Mean } \\
\text { Egg/Female }\end{array}$ & Mean Egg No. & $\begin{array}{c}\text { Mean } \\
\text { Egg/Female }\end{array}$ & Mean Egg No. & $\begin{array}{c}\text { Mean } \\
\text { Egg/Female }\end{array}$ \\
\hline $\mathrm{HbLE}_{\mathrm{EtOH}} 70 \%$ & $56.7 \pm 2.02^{\mathrm{c}}$ & $3.78 \pm 0.13^{c}$ & $102.8 \pm 3.04^{\mathrm{c}}$ & $6.85 \pm 0.20^{\mathrm{c}}$ & $156.5 \pm 4.59^{\mathrm{c}}$ & $10.43 \pm 0.30^{\mathrm{c}}$ \\
\hline SoLEEtOH70\% & $72.8 \pm 1.40^{\mathrm{b}}$ & $4.86 \pm 0.09^{b}$ & $139.3 \pm 1.45^{\mathrm{b}}$ & $9.29 \pm 0.09^{b}$ & $250.5 \pm 7.11^{\mathrm{b}}$ & $16.70 \pm 0.47^{b}$ \\
\hline Control (EtOH 70\%) & $93.8 \pm 1.47^{\mathrm{a}}$ & $6.26 \pm 0.1^{\mathrm{a}}$ & $172.3 \pm 1.28^{\mathrm{a}}$ & $11.49 \pm 0.08 \mathrm{a}$ & $372.3 \pm 10.98^{\mathrm{a}}$ & $24.82 \pm 0.73^{\mathrm{a}}$ \\
\hline
\end{tabular}

Table (2): Repellence index (RI) of the HbLE $\mathrm{EtOH}_{0 \%}$ and SoLEEtOH70\% summed after $72 \mathrm{~h}$ on T. urticae adult females using one sublethal concentration $(0.5 \%)$.

\begin{tabular}{ccccc}
\hline \multirow{2}{*}{ Plant extracts } & \multicolumn{3}{c}{$\mathrm{RI}^{1}$} & \multirow{2}{*}{ Classification } \\
\cline { 2 - 4 } & $24 \mathrm{~h}$ & $48 \mathrm{~h}$ & $72 \mathrm{~h}$ & \multirow{2}{*}{ Repellent } \\
\hline HbLEEtOH70\% & $0.00 \pm 0.00$ & $0.00 \pm 0.00$ & $0.16 \pm 0.10$ & Repellent \\
\hline SoLEEtOH70\% & $0.33 \pm 0.33$ & $0.27 \pm 0.11$ & $0.40 \pm 0.17$ & .
\end{tabular}

${ }^{1}$ Repellent Index; $2 \mathrm{G} /(\mathrm{G}+\mathrm{P})$ where $\mathrm{G}=$ the number of mites in the treated disk and $\mathrm{P}=$ the number of mites in the control disk; <1 repellent; 1 neutral; $1>$ attractant.

Table (3): Oviposition deterrent index (ODI) of the HbLE $\mathrm{EtOH} 70 \%_{0}$ and SoLE $E_{\mathrm{EtOH} 70 \%}$ summed after $72 \mathrm{~h}$ on $T$. urticae adult females using one sublethal concentration $(0.5 \%)$.

\begin{tabular}{ccccc}
\hline \multirow{2}{*}{ Plant extracts } & \multicolumn{3}{c}{ ODI $^{1}$} & \multirow{2}{*}{ Classification } \\
\cline { 2 - 4 } & $24 \mathrm{~h}$ & $48 \mathrm{~h}$ & $72 \mathrm{~h}$ & Oviposition deterrent \\
\hline HbLE $_{\mathrm{EtOH} 70 \%}$ & 100 & 100 & 96.93 & Oviposition deterrent
\end{tabular}

1 Oviposition Deterrent Index; $[(\mathrm{C}-\mathrm{T}) /(\mathrm{C}+\mathrm{T})]^{*} 100$ was calculated, where $\mathrm{C}$ and $\mathrm{T}$ represent eggs laid on control and treated disk.

females was considerably affected by $\mathrm{HbLE}$ EtOH70\%

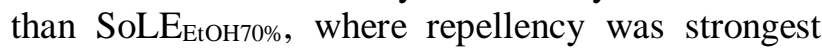
after 24 and $48 \mathrm{~h}$ post-treatment. Both extracts were classified as repellent as their RI value was lower than 1-SD. Our results were in agreement with Pascual-Villalobos and Robledo (1999) who showed that Helichrysum decumbens leaf extract was repellent to the stored grain pest, Tribolium castaneum. As well, other members of the Asteraceae family had shown repellency effect against $T$. urticae (Mozaffari et al., 2012). S. officinalis leaf extract was found to be extremely repellent to $T$. urticae adult females as stated by Mohamed et al. (2015) and Waked (2016).

$\mathrm{HbLE}_{\mathrm{EtOH} 70 \%}$ prevents the adult females to lay eggs where the ODI ranging from $96.93-100.0 \%$ while $72.24-83.33 \%$ of ODI was recorded for SoLE $E_{\text {EtOH70\% }}$ after 24,48 and $72 \mathrm{~h}$, respectively. This finding was in accordance with that of Dimetry et al. (1993) who showed 100\% ODI of neem azal-S (Meliaceae) at $0.1 \%$ against T. urticae. Strong oviposition deterrent $(\mathrm{ODI}=100)$ was noted for ethanol crude plant extracts (up to 10\%) belonging to different families against Tetranychus truncates viz. neem and chinaberry (Meliaceae), cube root (Fabaceae) and sweet oleander (Apocynaceae) (Sakunwarin et al. 2004).

\section{Direct toxicity to $T$. urticae zero-time eggs}

Daily egg hatching percentage $( \pm \mathrm{SE})$ of zero-time eggs of T. urticae adult females treated with $8 \%$ of $\mathrm{HbLE}_{\mathrm{EtOH} 70 \%}$ and $\mathrm{SoLE}_{\mathrm{EtOH} 70 \%}$ at $27 \pm 2^{\circ} \mathrm{C}$ is shown in Table (4). Results showed that both extracts significantly affected egg mortality rates at $8 \%$. The egg hatching starts four days after treatment (DAT) for both extracts as compared to their control groups. Interestingly, all larvae turned into nymphs with no larval mortality in the control groups while treatment caused the death of all hatched larvae before reaching the nymphal stages.

Our results are in accordance with other studies related to the Asteraceae family where $X$. strumarium aqueous plant extracts exhibited $87.09 \%$ of $T$. urticae egg mortality (Sarmah et al., 2009). In contrast to our findings, Erdogan et al. (2012) determined that $H$. arenarium crude extract $(12 \%)$ did not show any ovicidal effects against $T$. urticae eggs. Regarding SoLE $E_{\mathrm{EtOH} 70 \%}$ on the other hand, our results showed that $\mathrm{SoLE}_{\mathrm{EtOH} 70 \%}$ at $8 \%$ caused $45.34 \pm 11.73 \%$ egg mortality which was higher than the methanolic leaf extract of $S$. officinalis as recorded by Salman et al. (2014) that caused 30.2\% eggs mortality at $12 \%$. This also was in accordance with Waked (2016) who recorded 35\% of egg mortality when treated with both the methanolic and 
aqueous leaf extracts of S. officinalis (20\%). In contradiction, Tomczyk and Suszko (2011) recorded the low ovicidal effect of the ethanolic leaf extract of $S$. officinalis against $T$. urticae eggs.

\section{GC-MS analysis of the $\mathrm{Hb}_{\mathrm{EtOH} 70 \%}$ and SoEtOHz0\% leaf extracts:}

The extracts were injected into the GC-MS analyzer to identify the major bioactive components. The $\mathrm{HbLE}_{\mathrm{EtOH} 70 \%}$ and SoLE $\mathrm{EtOH}_{70 \%}$ chromatograms is shown in (Figure 2). In total, five bioactive compounds from various classes of phytochemicals were identified in $\mathrm{HbLE}_{\mathrm{EtOH} 70 \%}$ as shown in Table (5). The main compounds were Phytol (58.79\%), 2-Bromolauric acid (8.18\%), Squalene (3.09\%), Phenols $(2.69 \%)$ and Benzene $(0.45 \%)$. The identified bioactive compounds of $\mathrm{SoLE}_{\mathrm{EtOH} 70 \%}$ is shown in Table (6). The main compounds were Phytol $(82.08 \%)$, Squalene $(2.05 \%)$, Neophytadiene (1.61\%), 6,9,12,15-Docosatetraenoic acid methyl ester $(0.69 \%)$ and 2,2,3,3,4,4-Hexadeutero Octadecanal $(0.12 \%)$.

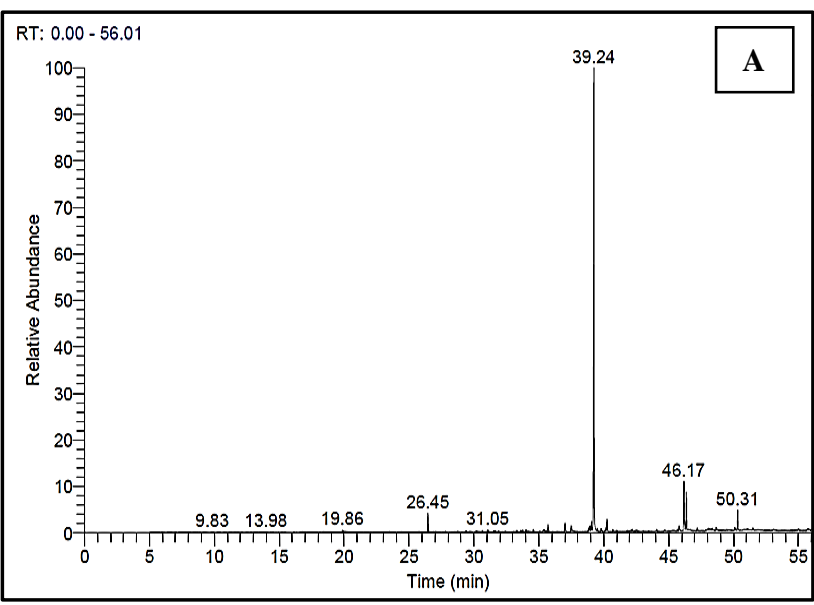

To the best of our knowledge, the phytochemistry of $H$. bracteatum leaf extract remained scarce, as it has not been investigated previously. According to our results, the acyclic diterpene alcohol, phytol was the major constituent of both the $H$. bracteatum and S. officinalis ethanolic leaf extracts. This was significantly different from the one previously reported by Veličković et al. (2003) who found that manool was the major component (9\%) in the ethanolic leaf extract of S. officinalis. While, Waked (2016) found that (1S,4R,5R) 4-Methyl-1-(propan-2-yl)bicycle[3.1.0]hexan-3-one (29\%) was the major compound in the methanolic leaf extract of $S$. officinalis. This difference observed in phytochemical screening could be ascribed to the ecological circumstances, the plant age, the extraction techniques, the solvent used, the concentration of its active components, the physicochemical characteristics, and the chemical composition of the extracts all these factors must influence the performance of the plant extracts (Ouahida et al., 2016).

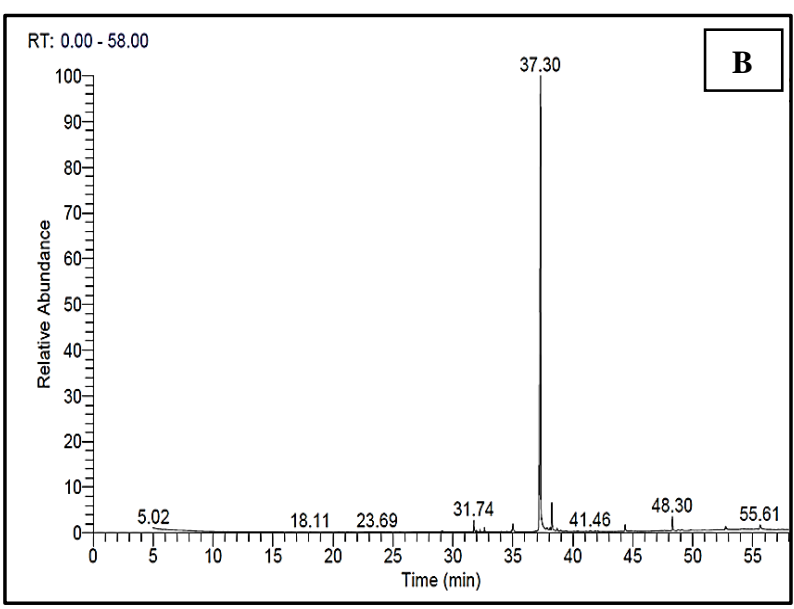

Fig. (2): GC-MS chromatogram of $\operatorname{HbLE}_{\mathrm{EtOH} 70 \%}(\mathrm{~A})$ and $\mathrm{SoLE}_{\mathrm{EtOH} 70 \%}$ bioactive components (B).

Table (4): Egg hatching percentage ( \pm SE) of T. urticae zero-time eggs treated with $8 \%$ of $\mathrm{HbLE}_{\mathrm{EtOH} 70 \%}$ and SoLE

\begin{tabular}{lcccccccc}
\hline & \multicolumn{4}{c}{ \% Egg hatching } & \multicolumn{3}{c}{ \% Larval mortality } \\
\cline { 2 - 9 } & 4 DAT & 5 DAT & 6 DAT & 7 DAT & 4 DAT & 5 DAT & 6 DAT & 7 DAT \\
\hline HbLEEtOH70\% & $20.05 \pm 4.25^{\mathrm{b}}$ & $41.46 \pm 12.68^{\mathrm{b}}$ & $48.75 \pm 15.38^{\mathrm{b}}$ & $48.75 \pm 15.38^{\mathrm{b}}$ & $60.56 \pm 11.07^{\mathrm{a}}$ & $70.96 \pm 6.45^{\mathrm{a}}$ & $100 \pm 0.0^{\mathrm{a}}$ & $100 \pm 0.0^{\mathrm{a}}$ \\
\hline SoLEEtOH70\% & $11.31 \pm 5.40^{\mathrm{b}}$ & $40.01 \pm 15.30^{\mathrm{b}}$ & $45.34 \pm 11.73^{\mathrm{b}}$ & $45.34 \pm 11.73^{\mathrm{b}}$ & $46.43 \pm 8.20^{\mathrm{a}}$ & $64.31 \pm 11.04^{\mathrm{a}}$ & $100 \pm 0.0^{\mathrm{a}}$ & $100 \pm 0.0^{\mathrm{a}}$ \\
\hline Control $_{\text {EtOH70\% }}$ & $73.67 \pm 7.72^{\mathrm{a}}$ & $98.81 \pm 0.7^{\mathrm{a}}$ & $98.81 \pm 0.7^{\mathrm{a}}$ & $98.81 \pm 0.7^{\mathrm{a}}$ & $0.00 \pm 0.00^{\mathrm{b}}$ & $0.00 \pm 0.00^{\mathrm{b}}$ & $0.00 \pm 0.00^{\mathrm{b}}$ & $0.0 \pm 0.00^{\mathrm{b}}$ \\
\hline
\end{tabular}

*DAT: Day After Treatment

Table (5): Chemical composition of the different bioactive components of the HbLE $E_{\text {EtOH70\% }}$ using GC-MS analysis

\begin{tabular}{cccccc}
\hline Peak & Retention Time (min) & Chemical Name & Molecular Formula & M wt. & Area \% \\
\hline 1. & 26.45 & Phenol & $\mathrm{C}_{15} \mathrm{H}_{24} \mathrm{O}$ & 220 & 2.69 \\
\hline 2. & 31.05 & Benzene & $\mathrm{C}_{17} \mathrm{H}_{28}$ & 232 & 0.45 \\
\hline 4. & 39.24 & Phytol & $\mathrm{C}_{20} \mathrm{H}_{40} \mathrm{O}$ & 296 & 58.79 \\
\hline 3. & 46.17 & 2-Bromolauric acid & $\mathrm{C}_{12} \mathrm{H}_{23} \mathrm{BrO}_{2}$ & 278 & 8.18 \\
\hline 5. & 50.31 & Squalene & $\mathrm{C}_{30} \mathrm{H}_{50}$ & 410 & 3.09 \\
\hline
\end{tabular}


Table (6): Chemical composition of the different bioactive components of the SoLE $E_{\mathrm{EtOH} 70 \%}$ using GC-MS analysis

\begin{tabular}{cccccc}
\hline Peak & Retention Time $(\mathrm{min})$ & Chemical Name & Molecular Formula & M wt. & Area \% \\
\hline 1. & 31.74 & Neophytadiene & $\mathrm{C}_{20} \mathrm{H}_{38}$ & 278 & 1.61 \\
\hline 2. & 37.30 & Phytol & $\mathrm{C}_{20} \mathrm{H}_{40} \mathrm{O}$ & 296 & 82.08 \\
\hline 3. & 41.46 & $2,2,3,3,4,4-$ Hexadeutero Octadecanal & $\mathrm{C}_{18} \mathrm{H}_{30} \mathrm{D}_{6} \mathrm{O}$ & 268 & 0.12 \\
\hline 4. & 48.30 & Squalene & $\mathrm{C}_{30} \mathrm{H}_{50}$ & 410 & 2.05 \\
\hline 5. & 55.61 & \multirow{2}{*}{$6,9,12,15$-Docosatetraenoic acid methyl ester } & $\mathrm{C}_{23} \mathrm{H}_{38} \mathrm{O}_{2}$ & 346 & 0.69 \\
\hline
\end{tabular}

Phytol showed many biological activities viz. antibacterial, anti-inflammatory, and insecticidal potentials (Kumar et al., 2010). It was observed by Odalo et al. (2005) that phytol had a high repellent activity against Anopheles gambiae. Squalene is the most common triterpene found in high concentration in different Helichrysum species (Lourens et al., 2008). These species are generally enriched source of phenolics, $\alpha$-pyrone and acetophenones derivatives responsible for its biological activities (Kladar et al., 2015). It was established that phenols and its derivatives are toxic to humans and animals due to the formation of phenoxyl radicals (Andersen, 2006). Salvia species are also characterized by different secondary metabolite constituents responsible for their bioactivities (Simmonds and Blaney, 1992). In addition to phytol, squalene, a tripenoid hydrocarbon, the neophytadiene was also detected possessing strong bactericidal, antifungal and antimicrobial activities (Venkata et al., 2012). Hence, the extracts toxicity and repellency were possibly associated with the presence of diterpene, triterpene, and phenolic compounds (Tomczyk and Suszko, 2011). The observed acaricidal characteristics were mostly attributed to the synergetic effect of multiple major and minor compounds present at various concentrations.

In conclusion, the current study confirmed that $H$. bracteatum leaf extract had both lethal and repellent effects stronger than $S$. officinalis against T. urticae under laboratory conditions. H. bracteatum leaf extract can be used effectively as an acaricidal product for the management of T. urticae, but it is not suitable for use in integrated pest management (IPM) strategies due to its toxic effects against S. gilvifrons. Meanwhile, S. officinalis leaf extract can be used effectively as a harmless phyto-pesticidal product suitable for use in IPM strategies as it was safe for $S$. gilvifrons. Thus, the aromatic medicinal plant extracts tested in our study demonstrated potent acaricidal properties that have the potential to be established as natural insecticides. The permanent plant investigations have opened up a new perspective in finding alternatives to chemical acaricides.

\section{ACKNOWLEDGMENTS}

We are thankful to Prof. Dr. Marguerite A. Rizk, Vegetable \& Ornamental Plant Mites Dept., Plant Prot. Res. Inst., Agric. Res. Center, for her kind help and contribution in this work.

\section{REFERENCES}

Andersen, A. 2006. Final report on the safety assessment of sodium p-chloro-m-cresol,pchloro-m-cresol, chlorothymol, mixed cresols, mcresol, o-cresol, p-cresol, isopropyl cresols, thymol, o-cymen-5-ol, and carvacrol. International Journal of Toxicology, 25: 29-127.

Beheshti-Rouy, M.; Azarsina, M.; Rezaie-Soufi, L.; Alikhani, M. Y.; Roshanaie, G. and Komaki, S. 2015. The antibacterial effect of sage extract (Salvia officinalis) mouthwash against Streptococcus mutans indental plaque: a randomized clinical trial. Iran Journal of Microbiology, 7: 173-177.

Biddinger, D. J.; Weber, D. C. and Hull, L. A. 2009. Coccinellidae as predators of mites: Stethorini in biological control. Biological Control, 51: 268283.

Breuer, M. and Devkota, B. 1990. Control of Thaumetopoea pityocampa (Den. \& Schiff.) by extracts of Melia azedarach L. (Meliaceae). Journal of Applied Entomology, 110: 128-135.

Chiasson, H.; Bostanian, N. J. and Vincent, C. 2004. Acaricidal properties of a Chenopodium-based botanical. Journal of Economic Entomology, 97: 1373-1377.

Dimetry, N. Z.; Amer, S. A. A. and Reda, A. S. 1993. Biological activity of two neem seed kernel extracts against the two-spotted spider mite Tetranychus urticae Koch. Journal of Applied Entomology, 116: 308-312.

El Ouali Lalami, A.; El-Akhal, F.; Ez Zoubi, Y. and Taghzouti, K. 2016. Study of Phytochemical Screening and Larvicidal Efficacy of Ethanolic Extract of Salvia officinalis (Lamiaceae) from North Center of Morocco against Culex pipiens 
(Diptera: Culicidae) Vector of Serious Human Diseases. International Journal of Pharmacognosy and Phytochemistry Research, 8: 1663-1668.

Erdogan, P.; Yildirim, A. and Sever, B. 2012. Investigations on the effects of five different plant extracts on the two-spotted mite Tetranychus urticae Koch (Arachnida: Tetranychidae). Psyche: AJournal of Entomology, 2012: 1-5.

Grbic, M.; Van Leeuwen, T.; Clark, R.; Rombauts, S.; Rouzé, P.; Grbić, V.; Osborne, E. J.; Dermauw, W.; Cao, P. and Ngoc, T. 2011. The genome of Tetranychus urticae reveals herbivorous pest adaptations. Nature, 479: 487-492.

Helle, W. and Overmeer, W. P. J. 1985. Rearing techniques. Spider mites: their biology, natural enemies and control. Elsevier Science Publishers B.V., Amsterdam - Printed in The Netherlands, ELSEVIER Amsterdam - Oxford - New York Tokyo. PP: 331-335.

James, D. G. 2003. Pesticide susceptibility of two coccinellids (Stethorus punctum picipes and Harmonia axyridis) important in biological control of mites and aphids in Washington hops. Biocontrol science and technology, 13(2): 253259.

Kladar, N. V.; Anackov, G. T.; Rat, M. M.; Srdenovic, B. U.; Grujic, N. N.; Sefer, E. I. and Bozin, B. N. 2015. Biochemical characterization of Helichrysum italicum (Roth) G. Don subsp. italicum (Asteraceae) from Montenegro: Phytochemical screening, chemotaxonomy, and antioxidant Properties. Chemistry and Biodiversity, 12: 419-431.

Kogan, M. and Goeden, R. D. 1970. The host-plant range of Lema trilineata daturaphila (Coleoptera:Chrysomelidae). Annals of the Entomological Society of America, 63: 11751180.

Kumar, P. P.; Kumaravel, S. and Lalitha, C. 2010. Screening of antioxidant activity, total phenolics and GC-MS study of Vitex negundo. African Journal of Biochemistry Research, 4(7): 191-195.

Kumral, N. A.; Çobanoglu, S. and Yalçın, C. 2010. Acaricidal, repellent and oviposition deterrent activities of Datura stramonium L. against adult Tetranychus urticae (Koch). Journal of Pest Science, 83: 173-180.

Kumral, N. A.; Çobanoğlu, S. and Yalçın, C. 2013. Sub-lethal and lethal effects of Datura stramonium L. leaf extracts on the European red mite Panonychus ulmi (Koch) (Acari: Tetranychidae) and its predator, Stethorus gilvifrons (Muls.) (Col.: Coccinellidae). International Journal of Acarology, 39: 494-501.

Lourens, A.; Viljoen, A. and Van Heerden, F. 2008. South African Helichrysum species: A review of the traditional uses, biological activity and phytochemistry. Journal of Ethnopharmacology, 119: 630-650.

Mazhawidza, E.; Mvumi, B. M. and Mazarura, U. 2018. Effects of crude aqueous extracts of indigenous pesticidal plants on the ladybird beetle, Hippodamia variegate (Goeze) (Coleoptera: Coccinellidae). International Journal of Tropical Insect Science, 38: 159-167.

Mohamed, F. S.; Hoda, E. H.; Darwish, Z. E.; Amer, S. A.; Salama, A. B. and El-Desouky, M. E. 2015. Influence of some extracts from three lamiaceae plants on toxicity, repellency and some biological aspects of Tetranychus urticae Koch (Acari: Tetranychidae). Egyptian Journal of Biological Pest Control, 25(1): 255-260.

Mozaffari, F.; Abbasipour, H.; Garjan, A. S.; Saboori, A. R. and Mahmoudvand, M. 2012. Various effects of ethanolic extract of Mentha pulegium on the two-spotted spider mite, Tetranychus urticae (Tetranychidae). Archives of Phytopathology and Plant Protection, 45: 1347-1355.

Odalo, J. O.; Omolo, M. O.; Malebo, H.; Angira, J.; Njeru, P. M.; Ndiege, I. O. and Hassanali, A. 2005. Repellency of essential oils of some plants from the Kenyan coast against Anopheles gambiae. Acta Tropica, 95(3): 210-218.

Ouahida, D.; Ouahrani, M. R. and Laouini, S. E. 2016. Influence of Extraction Method on Phytochemical Composition and Antioxidant Activity from Leaves Extract of Algerian Phoenix dactylifera L. International Journal of Current Pharmaceutical Review and Research, 7: 84-89.

Pascual-Villalobos, M. J. and Robledo, A. 1999. Anti-insect activity of plant extracts from the wild flora in southeastern Spain. Biochemical Systematics and Ecology, 27: 1-10.

Pavela, R. 2004. Insecticidal activity of certain medicinal plants. Fitoterapia, 75: 745-749.

Rott, A. S. and Ponsonby, D. J. 2000. The effect of temperature, relative humidity and host plant on the behaviour of Stethorus punctillum as a predator of the two-spotted spider mite Tetranychus urticae. BioControl, 45: 155-164.

Roy, M.; Broder, J. and Cloutier, C. 2005. Seasonal activity of the spider mite predators Stethours punctillum (Coleoptera: Coccinellidae) and Neoseiulus fallacis (Acarina: Phytoseiidae) in raspberry, two predators of Tetranychus mcdanieli (Acarina: Tetranychidae). Biological Control, 34: 47-57.

Sakunwarin, S.; Chandrapatya, A. and Baker, G. T. 2004. Toxicity, repellency and oviposition deterrence of crude plant extracts on Tetranychus truncates Ehara (Prostigmata: Tetranychidae). Thai Journal of Agricultural Science (Thailand), 37: 181-190.

Sala, A.; Recio, M. D. C.; Giner, R. M.; Máñez, S.; 
Tournier, H.; Schinella, G. and Rios J. L. 2002. Anti-inflammatory and antioxidant properties of Helichrysum italicum. Journal of Pharmacy Pharmacology, 54(3): 365-371.

Salman, S. Y.; Sarıtaş, S.; Kara, N. and Ay, R. 2014. Acaricidal and ovicidal effects of sage (Salvia officinalis L.) and rosemary (Rosmarinus officinalis L.) (Lamiaceae) extracts on Tetranychus urticae Koch (Acari: Tetranychidae). Journal of Agriculture Science Tarim Bilimleri Dergisi, 20: 358-367.

Sarmah, M.; Rahman, A.; Phukan, A. K. and Gurusubramanian, G. 2009. Effect of aqueous plant extracts on tea red spider mite, Oligonychus coffeae, Nietner (Tetranychidae: Acarina) and Stethorus gilvifrons Mulsant. African Journal of Biotechnology, 8: 417-423.

Simmonds, M. S. J. and Blaney, W. M. 1992. Labiatae-insect interactions: Effects of Labiataederived compounds on insect activity. In R. M. Harley \& T. Reynolds (Eds.), Advances in Labiate science. Royal Botanic Gardens Kew, United Kingdom, PP: 375-392.

Smith, C. M. and Clement, S. L. 2012. Molecular bases of plant resistance to arthropods. Annual Review of Entomology, 57: 309-328.

Thangavel, A.; Balakrishnan, S.; Arumugam, A.; Duraisamy, S. and Muthusamy, S. 2014.
Phytochemical screening, gas chromatography-mass spectrometry (GC-MS) analysis of phytochemical constituents and anti-bacterial activity of Aerva lanata (L.) leaves. African Journal of Pharmacy and Pharmacology, 8(5): 126-135.

Tomczyk, A. and Suszko, M. 2011. The role of phenols in the influence of herbal extracts from Salvia officinalis L. and Matricaria chamomilla $\mathrm{L}$. on two-spotted spider mite Tetranychus urticae Koch. Biological Letters, 48(2): 193-205.

Veličković, D. T.; Ranđelović, N. V.; Ristić, M. S.; Veličković, A. S. and Šmelcerović, A. A. 2003. Chemical constituents and antimicrobial activity of the ethanol extracts obtained from the flower, leaf and stem of Salvia officinalis L. Journal of the Serbian Chemical Society, 68: 17-24.

Venkata, R. B.; Samuel, L. A.; Saradhi, M. P.; Rao, B. N.; Krishna, N. V.; Sudhakar, M. and Radhakrishnan, T. M. 2012. Antibacterial, antioxidant activity and GC-MS analysis of Eupatorium odoratum. Asian Journal of Pharmaceutical and Clinical Research, 5: 99-106.

Waked, D. A. 2016. Bio-efficacy assessment of Sage, Salvia officinalis L. extracts on some biological aspects of spider mite, Tetranychus urticae Koch (Acari: Tetranychidae). Egyptian Journal of Agricultural Research, 94(3): 633-644. 